\title{
The Evolution OF ERGativity In IRANIAN LANGUAGES*
}

\author{
Yadgar KARIMI \\ University of Kurdistan \\ y.karimi@uok.ac.ir
}

\begin{abstract}
This paper presents an attempt to investigate the origins of ergativity in Iranian languages, drawing upon diachronic and synchronic analyses. In so doing, I will trace the development of the ergative structure back to Old and Middle Persian where, it is argued, the roots of ergativity lie. I will specifically show that the ergative pattern as currently obtained in the grammatical structure of some Iranian languages has evolved from a periphrastic past participle construction, the analogue of which is attested in Old Persian. It will further be argued that the predecessor past participle construction imparted a resultative construal in Old Persian and, subsequently, in the transition to Middle Persian, has assumed a simple past reading. The bottom-line of the analysis will be represented as a proposal regarding the nature of the ergative verb, to the effect that an ergative verb, as opposed to a regular (non-ergative) transitive verb, is semantically transitive, but syntactically intransitive.
\end{abstract}

\section{Keywords}

ergative structure; resultatives; past participle; Old Persian; Iranian languages

\section{Izvleček}

Članek poskuša z diahrono in sinhrono analizo prikazati izvor ergativnosti v iranskih jezikih. Avtor sledi razvoju ergativne strukture vse od stare in srednje perzijščine, kamor naj bi segale korenine ergativnosti, in pokaže, da se je ergativni vzorec, ki je prisoten v slovničnih strukturah nekaterih iranskih jezikov, razvil iz perifrastičnega preteklega deležnika, katerega vzporednice so najdene v stari perzijščini. Avtor trdi, da je predhodni pretekli deležnik vodil do nastanka rezultativov $\mathrm{v}$ stari perzijščini in je posledično ob prehodu $\mathrm{v}$ srednjo perzijščino privedel do enostavnega preteklika. V zadnjem delu analize avtor predstavi naravo ergativnih glagolov in predlaga, da so ergativni glagoli, v nasprotju z običajnimi (ne-ergativnimi) prehodnimi glagoli, semantično prehodni, a skladenjsko neprehodni.

\section{Ključne besede}

ergativna struktura; rezultativnost; pretekli deležnik; Stara perzijščina; Iranski jeziki

\footnotetext{
* I would like to thank an anonymous reviewer of ALA for insightful comments and helpful suggestions. Thanks are also due to Mojtaba Monshizadeh of Allameh Tabataba'i University, Tehran, for sharing with me his ideas and insights concerning some of the issues raised in an earlier draft of the paper.
}

Acta Linguistica Asiatica, 2(1), 2012.

ISSN: 2232-3317, http://revije.ff.uni-lj.si/ala/

DOI: 10.4312/ala.1.2.23-44 


\section{Introduction}

The term "ergative" is widely used to describe a case/agreement pattern in which the subject of an intransitive clause is marked similarly to the direct object of a transitive clause, and differently from the transitive subject (Dixon, 1994). The following examples from Northern Kurdish (Kurmanji) illustrate ergativity:

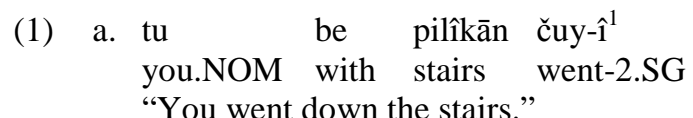

b. $\min$ tu dît-1̂

I.OBL you.NOM saw-2.SG

"I saw you."

c. te ez dît-im

you.OBL I.NOM saw-1.SG

"You saw me."

In (1a), the subject bears the nominative case and the intransitive verb enters into cross-reference with it. In the transitive clause, however, the verb establishes agreement with the direct object which is marked as nominative (1b-c). The emergent generalization seems to be that the verb in Kurdish shows agreement with the noun phrase that bears the nominative case. The pattern of case-marking and agreement in the Kurdish data is in full conformity with the definition of the ergative structure, given above. It is interesting to note that the subject in the transitive clause is marked as oblique.

The language system, and, concomitantly, its grammatical system, at any given stage of the development of the language is the natural outcome of the interplay of the independent operations and rules of the system. When described synchronically, some of these operations and rules are postulated under the guise of language-particular principles and patterns which are ultimately tantamount to ad hoc stipulations. For examples, the "unaccusative" status assigned to the transitive verb participating in an ergative structure has been derived from the theory-internal considerations in the perspective of which the overall analysis of ergativity is contextualized (Aldridge, 2008; Legate, 2008; Van de Visser, 2006). The result is the designation of the ergative verb as "exceptional", as opposed to the regular (non-Ergative) transitive verb which are designated as "accusative". Accounting for the status of "exceptionality" assigned to an ergative verb simply amounts to the restatement of the status quo in theoretical terms, without ever delving into the fundamental questions concerning the ontological status of the ergative verb.

1. The following abbreviations have been used in this paper: $1=$ first person; $2=$ second person; $3=$ third person; ACC=accusative; $\mathrm{DAT}=$ dative; $\mathrm{GEN}=$ genitive; IMPRF=imperfective; $\mathrm{NOM=nominative;}$ $\mathrm{OBL}=$ oblique; $\mathrm{PL}=$ plural; $\mathrm{PTCPL}=$ (past) participle; $\mathrm{SG}=$ singular. 
However, the diachronic investigations take up where the synchronic studies leave off, when it comes to the analysis of ergativity. Exploring why and how ergativity emerges in the Iranian languages, essentially, boils down to the investigation of the trajectory of the development of this grammatical pattern in the previous stages of these languages. Methodological considerations in conducting a linguistic research of a diachronic orientation impose a descriptive reductionism to the effect that the descriptive discussion of ergativity will be limited to Kurdish, in this paper. The pattern of ergativity and the grammatical properties associated with in Kurdish are taken to represent the ergative structure in the relevant Iranian languages. The diachronic discussion of ergativity will also be restricted to Old and Middle Persian. The only extant historical records the authenticity of which has long been acknowledged by scholars working in the field are from Old and Middle Persian (Kent 1953; Skjærvø 2005). To the extent that I have been able to ascertain, there is no historical document pertaining to a modern Iranian language, other than Persian, that has survived to the present day. Accordingly, given these empirical concerns, I will draw the data from Old and Middle Persian to trace the development of ergativity in Iranian languages back to its origin. However, this is not intended to mean that the modern Iranian languages in which the ergative structure obtains have been derived from Old and/or Middle Persian, rather, I believe, the close genealogical ties of modern Iranian languages and modern Persian makes it possible to extend the results ensuing from this investigation to other Iranian languages. Consequently, in this paper, data drawn from Kurdish will be taken to represent the current status of ergativity in Iranian languages and the data elicited from Old and Middle Persia will constitute the empirical domain based on which the diachronic analysis of ergativity will be conducted.

The linguistic analysis of almost every aspect of the syntax of Iranian languages presents a challenge to the researcher, as these languages are is a state of transition, typologically speaking. This class of languages is in the gradual process of undergoing a typological change from a highly inflectional type to an analytic type and this process of transition confronts the researcher who is trying to provide a purely synchronic study of the syntax of these languages with a stumbling block. The only way to circumvent the obstacle is to integrate the diachronic investigations into the synchronic analyses of the syntax of this set of languages. And, it is only the conflation of the diachronic and the synchronic studies that yields a possibly naturalistic picture of the syntax of Iranian languages.

To derive the syntax of ergativity in Iranian languages, I will draw on data from the earlier stages of Persian to argue that the pattern of ergativity historically descends from a periphrastic past participle construction in Old Persian which initially imparted a resultative meaning. The past participle construction further developed to convey a simple past construal in Middle Persian. It will, explicitly, be proposed that a structural extension of the past participle construction in Middle Persian serves as the immediate predecessor of ergativity in modern Iranian languages. The pursuit of the trajectory of the development of a past participle construction to an ergative construction will 
account for the "exceptional" status of the ergative verb as being "unaccusative". The ergative verb will be argued to be syntactically "intransitive" but semantically "transitive". This duality follows from the fact that the ergative verb in modern Iranian languages has retained the intransitive (nominal/adjectival) properties of its (past) participle predecessor, while it has assumed a fully-fledged transitive meaning characteristic of two-place predicates. Accordingly, the mixed properties of an ergative verb as straddling intransitivity and transitivity is the repercussion of the typological transition of the grammatical system of such languages from an inflectional type to an analytic one. The concomitant result of the discussion to be presented is that the regularity observed in the behavior of the non-ergative present tense transitive verbs as opposed to the ergative past transitive verbs stems from the relative typological stability reached in the present tense paradigm of these languages.

The structure of this paper is as follows: in section 2, the characteristic features of ergativity, with data chiefly drawn from Kurdish, will be discussed. Section 3 is devoted to the discussion of the past participle construction in Old Persian as the first stage in the development of ergativity. Section 4 presents the second stage of the development of ergativity in Middle Persian. In section 5, the consequences of the diachronic investigation for the synchronic analysis of ergativity will be evaluated. Section 6 constitutes the concluding remarks.

\section{The ergative construction: a description}

Ergativity in Iranian languages, and in Kurdish for that matter, obtains in the past tense clauses; that is to say, the Iranian languages display a tense-based split ergativity in their grammatical system. The non-past tense clauses in this class of languages tend to follow a nominative-accusative case/agreement system. The following data from Kurdish present the nominative-accusative alignment in the present tense clauses:

(2) a. ez di-kev-im

I.NOM IMPRF-fall-1.SG

"I am falling."

b. ez te di-bîn-im

I.NOM you.OBL IMPRF-see-1.SG

"I see you."

c. tu min di-bîn-î

you.NOM I.OBL IMPRF-see-2.SG

"You see me."

So far, we have seen that the present tense clauses in Kurdish abide by a nominative-accusative case/agreement pattern in that the subjects in an intransitive and a transitive clause are treated alike in terms of case/agreement whereas the direct object 
is marked differently (oblique). However, in the past tense clauses a different pattern emerges, as discussed before:

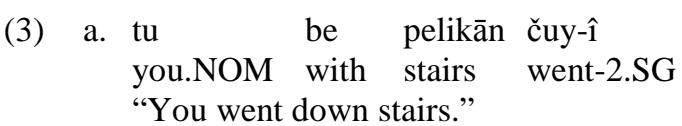

b. $\min$ tu dît-1̂

I.OBL you.NOM saw-2.SG

"I saw you."

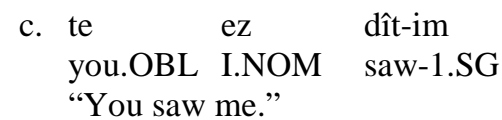

In (3a) a past intransitive clause is presented where the subject bears nominative case and the verb cross-references this nominative argument. However, in the past transitive clauses (3b-c), it is the direct object argument that takes the nominative case and triggers agreement on the verb. The subject argument in the past transitive clause is marked oblique. Generally speaking, in the past tense clauses in Kurdish, and in the ergative Iranian languages, the subject of an intransitive clause and the direct object of a transitive clause behave similarly in terms of case/agreement, and differently from the subject of a transitive clause.

That a selective range of Iranian languages conform to an ergative pattern in their case/agreement system is by no means a new finding (Bynon, 1979, 1989, 2005; Trask, 1979); in addition, some theoretically insightful accounts of ergativity in such languages have recently been put forward (Holmberg \& Odden, 2004; Karimi, 2010a,b; Van de Visser, 2006). The theoretical treatments of ergativity in general and of Iranian languages in particular share the theory-internal assumption that what makes an ergative transitive clause seem eccentric in terms of case/agreement, as opposed to the regular present tense (non-ergative) transitive clause, has to do with the nature of the ergative verb. These accounts, essentially, maintain the idea that an ergative transitive verb is defective in the sense that it is "unaccusative". In a theoretically neutral sense, an ergative transitive verb fails to license the accusative case on the direct object. While theoretically adequate and empirically correct, the "unaccusative" nature of the ergative transitive verb has not been the subject of a more fundamental investigation as to how and why an ergative verb is different from its non-ergative transitive counterpart. In other terms, the analyses proposed to derive the structure of ergative constructions have always begged the question of why an ergative transitive verb is "unaccusative" whereas its present-tense counterpart is "accusative". On an ontological level, working out an answer to this question will motivate a more realistic view of what an ergative construction essentially reduces to and will lead to a more naturalistic view of the ergative pattern in the paradigmatic system of these languages, as opposed to the non-ergative construction. 
Descriptively speaking, the two properties that characterize, and accordingly distinguish, the ergative pattern are as follows:

(4) a. the subject bears an oblique case.

b. the direct object bears a nominative case and controls agreement on the verb.

Coming up with a natural analysis that accounts for the properties (4a) and (4b) in the ergative structure of Iranian languages calls for a reassessment of this structure in terms of its diachronic evolution. This paper presents an attempt to delve into the historical development of the ergative structure as currently observed in Iranian languages. In the next section, I will broach the discussion by exploring the first stage of the development of ergativity in Old Persian.

\section{Old Persian: The first stage}

The linguists who have addressed themselves to the issue of the origin of ergativity in Iranian languages share the idea that the ergative construction is the natural extension and development of a "past participle construction" attested in the earlier stages of these languages (Benveniste, 1966; Cardona, 1970; Haig, 2008; Skjærvø, 1983; Statha-Halikas, 1979; Trask, 1979). As discussed before, due to the paucity of data of the earlier stages of the Iranian languages exhibiting ergativity, I will focus on data from Old and Middle Persian to investigate the trajectory of the development of ergativity.

\subsection{Case system in Old Persian}

The Old Persian and its sister Old Avestan constitute the oldest Iranian branch of the Indo-European family of languages. The extant written documents from Old Persian date back to the sixth to fourth centuries B.C. It is important to note that during the time that these documents were created, the Old Persian was already in the state of transition to Middle Persian; therefore, it is difficult to confidently decide that these texts precisely represent the Old Persian. However those working on the earlier stages of the Iranian languages consider the remnant texts as representing Old Persian and I follow the common practice in this respect. Bearing this in mind, let's turn now to the discussion of the case system in Old Persian.

Old Persian makes an extensive use of case-markers to distinguish the different grammatical functions a noun phrase assumes in the clausal syntax. Shown in the following is the list of the case-markers and their corresponding functions in Old Persian (see, Skjærvø 2005 for a fuller discussion on this and related issues):

- Nominative: to mark the subject in the passive, intransitive and transitive clauses. 
- Accusative: to mark the object of a transitive verb or of a preposition.

- Dative/genitive: the dative case-marker, though present in the earlier stages of the Old Persian, became extinct and its corresponding functions were taken up by the genitive marker. Accordingly, a genitive case-marker assumes the functions associated with both itself and the dative case-marker. The main functions denoted by the genitive case-marker are possessor marking and indirect object marking. However, it was occasionally used to mark the experiencer subject in a psychological state or the agent/ benefactive in a past participle construction.

The case-markers mentioned above are the only structural cases attested in Old Persian. In other words, for a given noun phrase to take any of these case-markers, that noun phrase must be in a certain grammatical (structural) position in the clause. Besides this set of case-markers, there are case-markers such as instrumental/ablative, vocative and locative that are called inherent (semantic) cases, the distribution of which is sensitive to the idiosyncratic (lexical) properties of the noun phrase they anchor to.

Having laid out this foundational background on the case system in Old Persian, I will turn now to the discussion of the past participle construction in Old Persian, which is widely believed to be the predecessor of the ergative construction.

\subsection{The past participle construction in Old Persian}

The category of verb in Old Persian was derived from four distinct stems: the present stem, the aorist stem, the participle stem and the perfect stem. The perfect stem was only attested in the earlier stages of the Old Persian and became extinct in the later stages of the development of the languages (Drinka 2003; Skjærvø 2005). The defunct perfect stem in Old Persian had been derived from its counterpart in Old Iranian. The perfect stem in Old Persian was synthetically derived from the verbal root and the reduplication of the initial consonant of the root coupled with a vowel (commonly " $a$ ") (Skjærvø 2005:104). The conflation of the reduplicated consonant and the vowel is attached to the verbal root as a prefix:

(5)

$$
\begin{array}{ll}
\sqrt{ } \mathrm{kar} & \text { "to do" } \\
{[\mathrm{k}+\mathrm{a}]+\sqrt{ } \mathrm{kar} \rightarrow \mathrm{kakār}} & \text { "have done" }
\end{array}
$$

However, as pointed out before, the synthetic perfect stem was no longer available in Old Persian and this left the paradigmatic tense/aspect system of Old Persian with a lacuna. To compensate for the deficiency, Old Persian resorts to an analytic construction consisting of a past participle stem and a copular verb. A clause with a perfect construal in Old Persian was thus constructed:

(6) agent/affected (genitive) + patient (nominative) + past participle + copular verb 
The following example exhibits a clause in Old Persian constructed according to the formula given in (6)
(7)
hamaranam kartam
$\varnothing$
then=3.PL.GEN battle.NOM
do.PTCPL.NOM be.3.SG
"Then they have fought the battle." (Kent, 1953, DB III, p. 19)

As concerns its distribution, a (past) participle falls into the category of adjectives. Descriptively speaking, a participle is a deverbal adjective. A clausal structure in which the predicate includes a past participle imparts a "resultative" meaning; that is to say, such a construction denotes a past event viewed from the present perspective. The interpretation conveyed by the periphrastic past participle construction is the same as the interpretation imparted by the already deceased synthetic perfect construction. Both yielded a "resultative" meaning.

The past participle construction represented schematically as (6) is widely believed to have triggered the development of ergativity in Iranian languages (Benveniste, 1966; Haig, 2008); however, what the previous work on the origin of ergativity in Iranian languages has failed to account for is the explicit trajectory of the development of the ergativity from the past participle construction. The scholars working on this topic have primarily engaged themselves with the issue of locating a starting-point which laid the foundation for the development of ergativity in Iranian languages. Nonetheless, the issue seems to have escaped the notice of previous scholars as to how the past participle construction precisely evolved to a construction which has come to be called ergative in modern Iranian languages. Although spotting the initial stages of the development of ergativity is a significant undertaking, it is only through the detection of the surmised trajectory of the development of ergativity from a past participle construction that we can be hopeful to provide a naturalistic account of how ergativity is derive in the present Iranian languages. For the results of the diachronic investigation of ergativity to be contextualized in a theoretical perspective, tracing the explicit stages that the ergative construction has undergone is indispensable.

The determination of the interpretation imparted by a past participle construction of the sort represented as (6) has been the subject of debate among the scholars focusing on this construction. The two dominant contentions in this regard are the possessive interpretation and the passive interpretation. Benveniste (1966) states that the past participle construction in Old Persian conveyed a possessive construal much in the same way manā pita "my father" did. At the same time, he highlights the parallelism between the possessive noun in a possessive construction and the agent noun in the past participle in (6); both bear the genitive case. On the other hand, he points out that in Old Persian, concurrently with the past participle construction, there has been a separate synthetic passive construction with its demoted agent realizing as a prepositional phrase. Therefore, according to Benveniste (1966), a passive construction is distinguished by the preposition hača "by" that licenses the demoted agent noun. 
Accordingly, based on these two observations, he maintains that the past participle construction in Old Persian was a possessive one and not passive.

Cardona (1970) argues against Benveniste's (1966) analysis and states that there are passive structures in Old Persian in which the agent noun bears a genitive case and, therefore, the mere presence of the genitive case on a noun does not imply that a structure is possessive. Cardona (1970) suggests that the past participle construction in Old Persian was passive with a genitive agent. Statha-Halikas (1979) states that Cardona's arguments concerning the structure of the past participle construction in Old Persian were not strong enough. He argues that the genitive case had become a versatile case in Old Persian assuming the functions already performed by other oblique cases. Hence, a possessive noun and a passive agent are equally marked by a genitive case, which is a cover oblique case. According to Statha-Halikas, taking the genitive case as the key to determining the semantic/structure of the past participle construction in Old Persian is not a plausible move.

Compiling the full range of past participle constructions in Old Persian, StathaHalikas (1979) and Skjærvø (1985) draw the descriptive observation that the majority of the attested past participle constructions in Old Persian texts are essentially agentless. Building on their observations, two general configurations can be envisaged in which a past participle predicate has participated:

(8) a. patient (nominative) + past participle + copular

b. agent/affected (genitive) + patient (nominative) + past participle + copular

The frequency of occurrence of the pattern represented as (8a) is much more than that of (8b) in Old Persian. These latter scholars, independently, believe that the agentless construction represented as (8a) imparted a perfect passive meaning while the construction in $(8 \mathrm{~b})$ with the agent noun expressed a perfect active meaning.

The frequency of occurrence reported in Statha-Halikas (1979) and Skjærv $\varnothing$ (1985) as a solution to settle the debate of interest is only suggestive and it is by no means conclusive. Although I do concur with the latter two scholars on the conclusions they draw, in the next section, I will present further formal evidences from Old Persian that corroborate the idea that the past participle construction as represented in (8b) did not implicate a passive construal.

\subsection{The active predecessor}

As discussed in the previous section, the past participle construction which is considered to be the forerunner of ergativity in the Iranian languages comes in two flavors: (a) with an agent participant and (b) without an agent participant. The following examples illustrate the past participles without an agent participant: 
(9) a. xšačam tya hacā amāxam taumāyā parābartam āha. kingdom.NOM which from our family taken-away.PTCPL be.PAST.3.SG "The kingdom which has been taken away from our family." (Kent 1953, DB I, 61-62)

b. vasiy aniyašciy naibam kartam anā Pārsā much other good do.PTCPL in Persepolis "Much other good (construction) has been built in Persepolis." (Kent, 1953, XPa, pp. 13-14)

c. tya Bardya avajata

that Smerdis slay.PTCPL

"That Smerdis has been slain." (Kent, 1953, DB I, p. 32)

And shown in the following examples are instances of the past participle construction with an overt agent participant.

(10) a. tya manā kartam

that.NOM 1.SG.GEN do.PTCPL

"That is what I have done." (Kent, 1953, DB I, p. 27)

b. ava $\theta \bar{a}=\check{s} \bar{a} \mathbf{m}$ hamaranam kartam then=3.PL.GEN battle.NOM fight.PTCPL.NOM

"Then they have fought the battle." (Kent, 1953, DB III, p. 19)

c. tya manā kartam utā tyamaiy piça kartam that.NOM 1.SG.GEN do.PTCPL and that.NOM=1.SG.GEN father.GEN do.PTCPL "That is what I have done and that is what my father has done." (Kent, 1953, XPa, pp. 19-20)

The constructions of interest in this paper are the past participle constructions with an agent participant as represented in (10a-c). In (10a), the agent noun bears the genitive/dative case and the patient noun is implied by the nominative relative pronoun which takes the patient participant as its antecedent. The genitive/dative agent noun has been cliticized to the second-position in (10b), and the patient participant hamaranam is marked by the nominative case. The data cited in (10c) provides evidence that, unlike the agent nouns in (10a-b) which are pronouns, a common noun phrase may be an agent participant, too.

It is recalled from section 3.2 that the interpretation of the past participle constructions with an agent participant ignited a controversy among the scholars analyzing such constructions. It is interesting to note that Kent (1953), from whose seminal work the data have been drawn, treats all the examples in (10a-c) as agented passive constructions ${ }^{2}$. However, based on the greater frequency of occurrence of the agentless past participle constructions, Statha-Halikas (1979) and Skjærvø (1985)

\footnotetext{
${ }^{2}$ The glosses given by Kent (1953) for the examples (10a-c) are, respectively, as follows:

i) It was done by me.

ii) Then the battle has been fought by them.

iii) It was done by me and that was done by my father.
} 
argued that the agentless past participle constructions were indeed passive structures whereas the agented past participle constructions imparted an active perfective meaning. It was also discussed that the frequency of occurrence may not constitute a strong argument for the conclusions read by these two scholars because it may be only a coincidence that the extant Old Persian texts contain more agentless past participle constructions than the agented counterparts, and hence they may not have truly reflected the syntax and the frequency of occurrence of such constructions.

In what follows, I will provide more direct evidence drawn from the structural properties of the agented past participle construction to argue that this construction conveyed an active perfective construal and not a passive one, along the lines of Statha-Halikas (1979) and Skjærvø (1985). It will specifically be illustrated that the dative/genitive agent clitic in the past participle construction merges in a high structural position which is typical of subjects. The properties/tests to be discussed include conjunction reduction, clitic placement and the synthetic vs. analytic passive coexistence which all point to the fact the agent clitic in the past participle construction enjoys a structurally and semantically high status which in turn renders the construction active (and not passive).

The first piece of evidence comes from the conjunction reduction test. A coordinate structure in which both conjuncts share a similar constituent can be rearranged so that the shared constituent in the second conjunct is omitted under identity with the antecedent constituent in the first conjunct. One of the frequent cases of conjunction reduction is the deletion of the shared subject(s) which is coreferential with the antecedent subject. It is a cross-linguistically valid generalization that it is only a canonical subject that can control the deletion of the coreferential subjects in the subsequent conjuncts. Now, let's turn to the data from Old Persian:

(11) ava $\theta \bar{a}=\check{s} a m$ hamaranam kartam utā avam Vahyazdātam agarbāya then=3.PL.GEN battle fight.PTCPL and that Vahyazdata took-prisoner.3.PL

tā martiya tyašaiy fratamā anušiyā āhata agarbāya and men who=3.SG.GEN foremost followers were arrested.3.PL

"They have fought a battle, and have arrested Vahyazdata, and have arrested his foremost followers." (Kent, 1953, DB III, pp. 47-49)

The above data lend credence to an analysis in which the dative/genitive agent in the past participle constructions in Old Persian occupies the syntactic subject position. In (11), the subject in the second and third conjuncts has been elided under the identity with the subject in the first conjunct. Therefore, it suggests that in Old Persian the genitive/dative agent in the past participle construction is treated as high in the clause structure as a canonical subject. The degree of topicality the dative/genitive agent noun enjoys in a past participle construction is in sharp contrast with the measure of topicality assumed by a demoted agent phrase in a passive construction (e.g., by-agent in English). The natural reading of the chain of coordinate constructions in (11) imposes a topical construal of the dative/genitive agent NP which enables it to license 
all subsequent occurrences of the elided subjects; whereas in a passive construction the topicality of the agent is further demoted due to its low position in the clause structure, and hence the failure to license conjunction reduction.

The discrepancy observed in the behavior of nominative and oblique clitics constitutes the second piece of evidence pointing to an active interpretation of an agented past participle construction. In Old Persian, nominative clitics remain in their base-generated position and do not undergo movement. However the oblique clitics undergo movement and this movement is to the second position in a clause. Among the oblique clitics, however, only accusative and genitive/dative clitics bear the ability to undergo movement (Haig, 2004, pp. 155-158). It, then, follows that the dative/genitive case, constituting a natural class with the accusative case, is licensed structurally much in the same way the accusative case is (Chomsky, 1981). A structural case is assigned to a noun phrase that is part of the argument structure of the verb and accordingly, it becomes evident that the genitive/dative agent is licensed as part of the argument structure of the verb. This is while a demoted agent noun phrase in a passive clause is not part of the canonical argument structure and assumes a peripheral position:

(12) a. aita=maiy Auramazdā dadātuv this=1.SG.GEN Ahuramazda may.give "May Ahuramazda give this to me." (Kent, 1953, DNa, pp. 53-55)

b. Auramazdā=maiy upastām abara Ahuramazda=1.SG.GEN aid bore.3.SG

“Ahuramazda bore me aid (helped me).” (Kent, 1953, DB I, pp. 87-88)

The data in (12a-b) show that, along with the dative/genitive clitic, an accusative clitic may undergo movement to the second-position in a clause in Old Persian.

The last piece of evidence is drawn from the empirical observation that in Old Persian a synthetic passive construction co-existed with the agented past participle construction. Given the economy-driven considerations, it is logical to argue that the concurrent existence of a synthetic passive construction in the Old Persian has obviated the need to develop a parallel passive construction serving the same purposes. The agent noun phrase in the synthetic passive in Old Persian came in three different guises: (a) as a preposition phrase governed by the preposition hač "from", (b) as a preposition phrase followed by the postposition rādiy "by", and (c) as a genitive/dative marked noun. Although the attested data representing the synthetic passive in Old Persian texts are scarce, it is patently obvious that each incarnation of the agent phrase in the synthetic passive has been determined by the idiosyncratic properties of the verb:

(13) utā=šam Auramazdā naiy ayadiya and=3.PL.GEN Ahuramazda NEG worshiped.PASS

"And Ahuramazda was not worshiped by them." (Kent, 1953, DBV, pp. 15-16)

A further interesting point to note concerning the synthetic passive exemplified in (13) is the passive morphology on the verb. While in an agented past participle 
construction, the predicate is realized as a past participle form of the verb, in the synthetic passive construction the passive verb takes the passive morphology. This in turn counts as a supporting evidence for the fact that the agented past participle construction in Old Persian has not been passive.

In the next section, I will address the syntactic derivation of the agented past participle construction which is argued to have constituted the initial impetus in the development of ergativity in the Iranian languages.

\subsection{Deriving the syntax of the past participle construction}

It was discussed in section 2.2 that the periphrastic past participle construction was a system-internal compensatory strategy to replace the defunct synthetic perfect construction. This paradigmatic choice was motivated by the identity of the interpretation read off from a past participle construction. The semantic yield of a past participle construction is a "resultative" construal and this is precisely the interpretation which ensued from the extinct synthetic perfect construction. As far as I have been able to verify, the data attested in the Old Persian texts do not include a past participle construction in which both the agent and the patient participants are realized as common nouns in one clause. In the attested data, either the patient is realized as a relative pronoun and the agent as a common noun, or the patient is realized as a common noun and the agent as a clitic. To illustrate how a past participle is syntactically derived, I will reconstruct a past participle construction where both the agent and the patient are common nouns. In fact, the reconstructed example is a conflation of the constituents in (10b) and (10c):

(14) maiy pica hamaranam kartam

1.SG.GEN father.GEN battle.NOM do.PTCPL

"My father has fought the battle."

The following is the syntactic structure I propose to derive a past participle construction: 


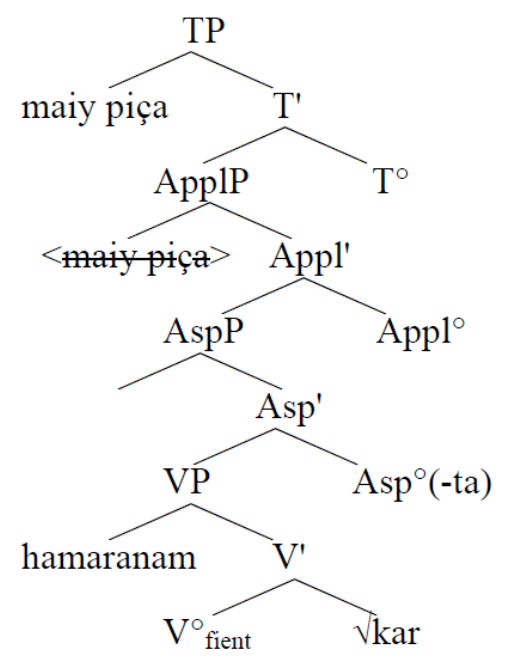

Figure 1: The past participle construction

Building on work couched within the Distributed Morphology framework (Halle \& Marantz, 1993) and proposals put forward in Embick (2004), I assume that the root merges with an abstract fientive verb which serves to convert the root into a fullyfledged verb ${ }^{3}$. The traditional parsing of a past participle distinguishes two components, which largely corresponds to the result ensuing from the Distributed Morphological parsing of the past participle:

(15) a. $\sqrt{ }$ kar "root"

b. $\sqrt{ } k a r+$ verbalizer

c. $\sqrt{ } k a r+$ verbalizer $+t a$ (participle stem marker)

d. Karta "the past participle stem"

In the traditional grammars of Old Persian, "- $t a$ " has been considered the past participle marker which turns a root into a past participle stem (Skjærvø, 2005, p. 97). The verbalizer component which corresponds to the fientive verb is phonologically null in Old Persian. Following Embick's (2004) proposals to derive the syntactic structure of a resultative construction, I will assume that the object (patient) is merged as the specifier of the fientive verb, extending it into a verb phrase (VP). Along the lines of Embick (2004), I also assume that what has traditionally been termed "participle marker" in Old Persian is, in fact, the instantiation of the aspect head in syntax. It is this aspectual head merged with the eventive VP that renders the whole structure resultative in interpretation. A noteworthy feature of the past participle construction in Old Persian is that the VP is not merged with a causative $\mathrm{v}^{\circ}$ to project

\footnotetext{
${ }^{3}$ In Distributed Morphology, roots are syntactically the minimal category-neutral elements that enter the derivation of sentences with an abstract core of meaning (Marantz, 1997). For a root to assume a grammatically independent status, it must combine with a syntactic category-assigner element. In the present case, a fientive verbalizer turns the root into a verb.
} 
into vP. This is because the past participle construction, being resultative semantically, denotes a final state in which the direct object is found in relation to whole event.

The subject/affected in the past participle construction in Old Persian bears dative case. Incorporating ideas developed originally in Marantz (1993) and later elaborated in Cuervo (2003) and Pylkkänen (2002, 2008), I assume that the subject/affected, being dative, is applied to the whole AspP as the specifier of a high applicative head ${ }^{4}$. Semantically, the subject in the past participle construction in Old Persian is assigned a benefactive interpretation. For example the past participle construction hya manā kartam is ambiguous as between "this is what I have done" with the agentive reading of the subject, or "this is what has been done to my interest' with a benefactive reading of the subject. The last step in the derivation is the introduction of the tense phrase (TP). The head $\mathrm{T}^{\circ}$ enters into agreement with the patient NP which is already caseless in the derivation. This is because, as discussed before, the predicate in the VP is a participle and not a fully-fledged transitive verb, and since participles share adjectival/nominal properties, they fail to assign an accusative case to the patient. As a result of the $\mathrm{T}^{\circ}$-patient agreement, the patient noun phrase receives the nominative case $^{5}$.

In the next section, the route of the development of the ergative construction will be further traced in Middle Persian.

\section{Middle Persian: The second stage}

The past participle construction in Middle Persian represents the second stage of the development of ergative construction in Iranian languages. As extensively discussed in section 3, the paradigmatic tense/aspect system of Old Persian included four verbal stems: the present stem, the aorist stem, the perfect stem and the participle stem. Of these four stems, the perfect stem which contributed a synthetic perfect tense/aspect became defunct and was no longer available as a paradigmatic choice in the tense/aspect system in the later stages of the language. To make up for the gap, Old Persian resorted to the past participle stem to construct periphrastic structures imparting the resultative meaning typical of a perfect construction.

\footnotetext{
${ }^{4}$ In the current approaches to event/argument structure, an argument which is not directly engaged in the event denoted by the verb phrase is licensed by an applicative head. The interpretation assigned to an applied argument is thus: the action/state denoted by the verb phrase is in the interests of the applied argument. In languages in which an experiencer argument is marked dative in a psychological construction, it is argued that the experiencer is licensed as an applied argument. For example the Spanish "John (dative) likes the cake" is analyzed as "the cake is appealing to John (dative). The state denoted by the verb phrase "the cake is appealing" is oriented toward the applied argument "John".

${ }^{5}$ A point worthy of mention, in passing, concerns the declension of the past participle itself. It is evident from the examples that the past participle, constituting part of the predicative structure, bears nominative case. This empirical fact gives further credence to the stance that the past participle was still retaining nominal properties in Old Persian. Case in Old Persian was restricted to showing up on the categories endowed with the $[+\mathrm{N}]$ feature.
} 
However, the reduction in the tense/aspect oppositional system of Old Persian did not reach a terminus at that stage, rather it extended to Middle Persian with much greater effects. The tense/aspect system further reduced in Middle Persian to the effect that only the participle stem and the present stem were retained. In other words, the additional reduction in Middle Persian resulted in the extinction of the aorist aspect. The logical candidate to substitute the now defunct aorist stem was the past participle stem. Consequently, the following form-function correspondences emerged:

\begin{tabular}{||l|l||}
\hline FORM & FUNCTION \\
\hline \hline Present stem & Present tense \\
\hline Aorist stem & Past tense \\
\hline Participle stem & Predicative adjective \\
\hline Perfect stem (defunct) & Perfect tense/aspect \\
\hline
\end{tabular}

\begin{tabular}{||l|l||}
\hline FORM & FUNCTION \\
\hline \hline Present stem & Present tense \\
\hline Aorist stem & Past tense \\
\hline \multirow{3}{*}{ Participle stem } & Predicate adjective \\
\cline { 2 - 2 } & Perfect aspect/tense \\
\hline
\end{tabular}

Figure 2: Old Persian

\begin{tabular}{||l|l|}
\hline FORM & FUNCTION \\
\hline \hline Present stem & Present tense \\
\hline Aorist stem (defunct) & Past tense \\
\hline \multirow{3}{*}{ Participle stem } & Predicate adjective \\
\cline { 2 - 2 } & Perfect aspect/tense \\
\hline
\end{tabular}

\begin{tabular}{|c|c|}
\hline FORM & FUNCTION \\
\hline Present stem & Present tense \\
\hline Participle stem & $\begin{array}{l}\text { Predicate adjective } \\
\text { Perfect aspect/tense } \\
\text { Past tense }\end{array}$ \\
\hline
\end{tabular}

Figure 3: Middle Persian

As of result of this further reduction, the past participle stem assumed the pasttense-marking function which was already born by the aorist stem. Along with the typological change of the Middle Persian from a highly inflectional type to an analytic type, most of the inflectional morphology associated with the nominal/adjectival categories became detached. The common nouns, adjectives and pronouns no longer displayed morphological distinctions for such categories as case and gender. The case system reduced to two cases of nominative (direct) and oblique (indirect). The case marking on the past participle stem did not survive either.

Of particular importance to the present discussion is the fate of the past participle stem. The past participle stem has now a dual function of perfect-marking and pasttense-marking (its primary function as a predicative adjective aside). In order to increase the morphological markedness to establish a form-function parallelism and to unravel the intricacies brought about in the system for the mapping of the form onto the function, the past participle stem in Middle Persian underwent a process of "apocope" to the following effect. 
It is recalled from section 3 that the past participle stem in Old Persian was thus derived:

$$
\sqrt{ } \text { root }+ \text { verbalizer }+t a
$$

It was also mentioned that the final suffix $-t a$ was a participle-marker according to the traditional grammarians. In Middle Persian, the past participle underwent apocope and as result the final vowel $-a$, which corresponds to the participle-marker's vowel, was dropped. The remnant portion was treated as a past stem of the verb by the oppositional system of the language:

$$
\sqrt{ } \text { root }+ \text { verbalizer }+t
$$

An important point to note, however, is that Middle Persian retained the original past participle stem (16) to express the perfect tense/aspect, as in Old Persian. The following example from Middle Persian, with a simple past construal, shows how the past participle form has been reduced in form:

\section{(18) man abgust ahénd \\ I.OBL reveal-PTCPL copular.3.PL \\ "I revealed them." (Sundermann, 1989, p. 29)}

Since the past participle marker in Old Persian and later in Middle Persian had the invariant phonological form of $-t a$, all the simple past tense stems deriving from the process of apocope ended up with the final consonant $-t$. And this phonological form has continued to survive to the present time. The following lists illustrate a selective

\begin{tabular}{|c|c|c|c|c|c|c|}
\hline (19) a. & $\begin{array}{l}\text { košt } \\
\text { foruxt } \\
\text { kāšst } \\
\text { bāxt }\end{array}$ & $\begin{array}{l}\text { "killed" } \\
\text { "sold" } \\
\text { "implanted" } \\
\text { "lost" }\end{array}$ & $\begin{array}{l}\text { šost } \\
\text { nevešt } \\
\text { dašt } \\
\text { xord }^{6}\end{array}$ & $\begin{array}{l}\text { "washed" } \\
\text { "wrote" } \\
\text { "had" } \\
\text { "ate" }\end{array}$ & $\begin{array}{l}\text { andāxt } \\
\text { šenāxt } \\
\text { poxt } \\
\text { bord }\end{array}$ & $\begin{array}{l}\text { "threw" } \\
\text { "recognize" } \\
\text { "cooked" } \\
\text { "took" }\end{array}$ \\
\hline b. & $\begin{array}{l}\text { kušt } \\
\text { fïrošt } \\
\text { čānd } \\
\text { šušt }\end{array}$ & $\begin{array}{l}\text { "killed" } \\
\text { "sold" } \\
\text { "implanted" } \\
\text { "washed" }\end{array}$ & $\begin{array}{l}\text { xiwārd } \\
\text { bird } \\
\text { xist } \\
\text { kulānd }\end{array}$ & $\begin{array}{l}\text { "ate" } \\
\text { "took" } \\
\text { "threw" } \\
\text { "cooked" }\end{array}$ & $\begin{array}{l}\text { nāsānd } \\
\text { xusānd } \\
\text { kird } \\
\text { girt }\end{array}$ & $\begin{array}{l}\text { "introduced" } \\
\text { "soaked" } \\
\text { "did" } \\
\text { "held" }\end{array}$ \\
\hline
\end{tabular}
number of the past tense stems in modern Persian and Kurdish, respectively:

A shift in the interpretation of the eventuality encoded in the event structure including a past tense stem was the semantic yield of the reduction of the final vowel in the process of apocope and the concomitant change of the past participle stem into a simple past stem. The eventuality previously expressed by an event structure with a past participle construction was that of a stative/resultative predicate; however, the split in the form of the past participle stem and the associated split in function resulted in a

\footnotetext{
${ }^{6}$. The final $-t$ in the past tense stem undergoes voicing assimilation into $-d$ in the context of a preceding vowel or voiced consonant.
} 
shift from a "stative/resultative" interpretation to a "purely eventive/dynamic" interpretation.

\section{Modern Iranian languages: The final stage}

The hypothesis defended in this paper is that the ergative structure as currently obtains in a wide range of Iranian languages is the natural extension and development of the past participle and the subsequent past tense construction in the previous stages of these languages, much similar to what happened in the case of Old Persian. The diachronic investigation of the development of ergativity in Old Persian and Middle Persian has immediate implications for the synchronic study of ergative structure in modern Iranian languages.

To begin with the ergative (past transitive) verb, the "exceptional" status ascribed to this class of verbs receives a natural explanation. As is recalled from section 2, the past transitive (ergative) verb has long been recognized as an exceptional verb, as opposed to the regular present transitive verb, in that it fails to assign the accusative case to its object. In theoretical terms, the ergative verb is defective in the sense that it is "unaccusative". According to the diachronic analysis, the current past transitive (ergative) verb has been derived from a past participle stem attested in the earlier stages of these languages. This trajectory of development implies that the current past transitive (ergative) verbs have still retained the syntactic properties of their predecessor, i.e., the past participle. They share with their predecessor the syntactic nominal/adjectival properties and, as a result, fail to assign the (structural) accusative case to their direct object. In the generative tradition of syntactic analysis, the syntactic categories specified for the feature $[+\mathrm{N}]$ are not case-assigners (Chomsky, 1970, 1981). The $[+\mathrm{N}]$ feature bring nouns and adjective together in a class and sets them in contrast with the syntactic categories endowed with [-N] feature that are case-assigners (verbs and prepositions). Accordingly, the diachronic investigation of ergativity in Iranian languages reveals that the current past transitive verbs are semantically "transitive", but syntactically "intransitive".

As for the oblique case showing up on the subject in the past transitive (ergative) construction, it is recalled that the ergative structure had a predecessor with a resultative construal and that the subject in such constructions was licensed in an applicative phrase, with the applicative head assigning the dative/genitive case to it. As with the past transitive verb, I assume that the subject in the past transitive clause enjoys an in-between status, being semantically an agent but syntactically an applied argument.

The last point to note concerns the nominative case on the direct object in the ergative (past transitive) constructions in Iranian languages. I will assume that the head Tense in the syntactic derivation enters into agreement with the potentially available 
direct object and renders it nominative. The following tree diagram represents the syntactic structure I propose for the ergative construction in Iranian languages:

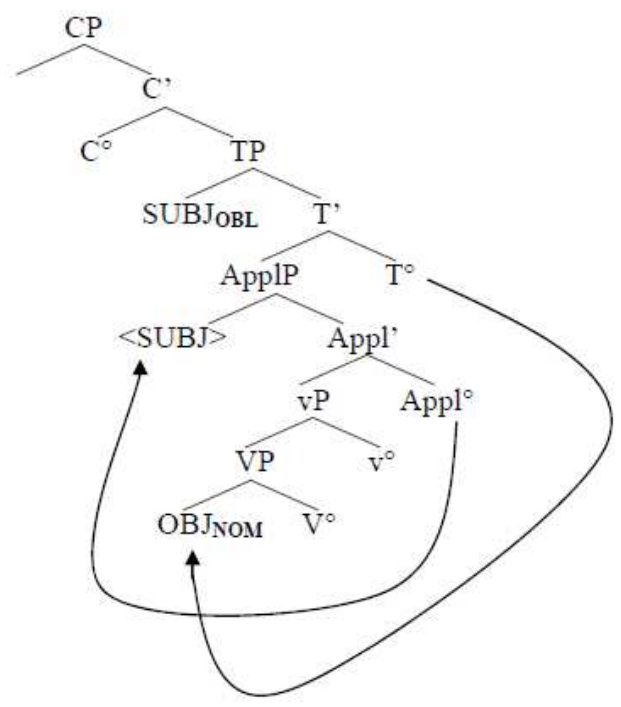

Figure 4: The structure of ergativity in Iranian languages

\section{Conclusion}

In this paper, I tried to provide a natural analysis of the syntactic structure of ergativity in Iranian languages, with data chiefly drawn from Kurdish, Old Persian and Middle Persian. In so doing, a diachronic investigation was carried out of how ergativity evolved in Iranian languages, and, consequently, the trajectory of the development of ergativity was drawn up from Old Persian to modern Iranian languages. Specifically, it was established that the ergativity in Iranian languages has as its origin a past participle construction with a resultative interpretation, attested in the earlier stages of these languages. The past participle construction underwent a functional extension in the more recent stages of these languages to impart a simple past meaning and this is the basis for the emergence of ergativity in the modern Iranian languages. Given the results ensuing from the diachronic investigation of ergativity, the questions concerning the nature of the ergative verb, the oblique subject and the nominative object in an ergative structure received a natural account.

The present work has as its tangential implication the proposition that the synchronic analyses should be accompanied by diachronic investigations when dealing with the syntactic structure of languages which are in the state of typological change, and that it is only a combination of the two types of study that give rise to natural accounts of the structure of these languages. 


\section{References}

Aldridge, E. (2008). Minimalist analysis of ergativity. Sophia Linguistica, 55, 123-142.

Benveniste, E. (1966). La construction passive du parfait transitif. In E. Benveniste (Ed.) Probl emes de linguistique generale (pp. 176-186). Paris: Gallimard.

Bynon, T. (1979). The ergative construction in Kurdish. Bulletin of the School of Oriental and African Studies, 42, 211-224.

Bynon, T. (1980). From passive to active in Kurdish via the ergative construction. In E. C. Traugott, R. Labrum \& S. Shepherd (Eds.) Papers from the 4th International Conference on Historical Linguistics (pp. 151-163). Amsterdam: Benjamîns.

Bynon, T. (2005). Evidential, raised possessor, and the historical source of the ergative construction in Indo-Iranian. Transactions of the Philological Society, 103, 1-72.

Cardona, G. (1970). The Indo-Iranian construction mana krtam. Language, 46, 1-12.

Chomsky, N. (1970). Remarks on nominalizations. In R. Jacobs \& P. Rosenbaum (Eds.) Readings in English Transformational Grammar (pp. 184-221). Waltham, MA: Ginn and Co..

Chomsky, N. (1981). Lectures on Government and Binding. Foris: Dordrecht.

Cuervo, M. C. (2003). Datives at large. Cambridge, MA: MIT dissertation.

Dixon, R. M. W. (1994). Ergativity. Cambridge: Cambridge University Press.

Drinka, B. (2003). The Perfect in Indo-European. Stratigraphic evidence of prehistoric areal influence. In H. Andersen (Ed.) Language contacts in prehistory. Studies in stratigraphy (pp. 77-105). Amsterdam: Benjamins.

Embick, D. (2004). On the structure of resultative participles in English. Linguistic Inquiry, 35, 355-392.

Haig, G. (1998). On the interaction of morphological and syntactic ergativity: Lessons from Kurdish. Lingua, 105, 149-173.

Haig, G. (2004). Alignment in Kurdish: A diachronic perspective. Unpublished Habilitationsschrift: Philosophische Fakultät der Christian-Albrechts-Universität zu Kiel

Haig, G. (2008). Alignment change in Iranian languages: a construction grammar approach. New York: Mouton de Gruyter.

Hale, K. \& Keyser, S. J. (1993). On argument structure and the lexical expression of semantic relations. In K. Hale \& S. J. Keyser (Eds.) The View from Building 20 (pp. 53-109). MIT Press, Cambridge Mass.

Hale, K. \& Keyser, S. J. (2002). Prolegomenon to a Theory of Argument Structure. Cambridge, MA: MIT Press.

Halle, M. \& Marantz, A. (1993). Distributed morphology and the pieces of inflection. In K. Hale \& S. J. Keyser (Eds.) The View from Building 20 (pp. 111-176). MIT Press, Cambridge Mass.

Holmberg, A. \& D. Odden. (2004). Ergativity and role-marking in Hawrami. Paper presented at Syntax of the World's Languages (SWL 1), Leipzig, Germany.

Karimi, Y. (2010a). Unaccusative transitives and the Person-Case Constraint effects in Kurdish. Lingua, 120, 693-716.

Karimi, Y. (2010b). Ergativity: Its origin and nature. $\mathrm{PhD}$ dissertation, Allameh Tabataba'i University, Teheran.

Kent, R. (1953). Old Persian. New Haven, Connecticut: American Oriental Society.

Legate, J. (2008). Morphological and abstract case. Linguistic Inquiry, 39, 55-101. 
Marantz, A. (1993). Implications of asymmetries in double object constructions. In S. Mchombo (Ed.) Theoretical aspects of Bantu grammar (PP. 113-150). Stanford, CA: CSLI.

Marantz, A. (1997). No escape from syntax: Don't try morphological analysis in the privacy of your own lexicon. In A. Dimitriadis, L. Siegel, C. Surek-Clark, \& A. Williams (Eds.) Proceedings of the 21st Annual Penn Linguistics Colloquium (pp. 201-225). Pennsylvania Working Papers in Linguistics 4.2. Philadelphia: University of Pennsylvania, Penn Linguistics Club.

Pylkkänen, L. (2002). Introducing Arguments. Ph.D. dissertation. MIT, Cambridge, MA.

Pylkkänen, L. (2008). Introducing Arguments. MIT Press, Cambridge MA.

Skjærvø, P. O. (1983). Case in Inscriptional Middle Persian, Inscriptional Parthian, and the Pahlavi Psalter. Studia Iranica, 12, 47-62.

Skjærvø, P. O. (1985). Remarks on the Old Persian verbal system. Münchner Studien zur Sprachwissenschaft, 45, 211-227.

Skjærvø, P. O. (2005). An introduction to Old Persian. Cambridge, Harvard.

Statha-Halikas, H. (1979). How not to tell a passive: the case of Old Persian mana krtam reconsidered. Berkeley Linguistic Society, 5, 350-361.

Sundermann, W. (1989). Mittelpersisch. In S. Rudiger (Ed.) Compendium Linguarum Iranicarum (pp. 138-164). Wiesbaden: Reichert.

Trask, L. (1979). On the Origins of Ergativity. In F. Plank (Ed.) Ergativity: Towards a Theory of Grammatical Relations (pp. 385-404). New York, New York: Academic Press.

Van de Visser, M. (2006). The marked status of ergativity. LOT Dissertation Series 141. 
